\title{
Nutraceutical and Cosmeceutical Products Containing Low Molecular Weight Peptides from Fermented Colostrum ${ }^{+}$
}

\author{
Ionuț Moraru 1, Angela Moraru 1,2, Anca Oancea ${ }^{3, *}$, Alexandra Gaspar-Pintiliescu ${ }^{3}$, \\ Viorica Coroiu ${ }^{3}$, Laura Stefan ${ }^{3}$, Andreea Iosăgeanu ${ }^{3}$, Teodora Ciucan ${ }^{2,3}$, Daniela Ilie ${ }^{3}$, \\ Cătălina Sanda ${ }^{3}$ and Ana-Maria Seciu-Grama ${ }^{3}$ \\ 1 Laboratoarele Medica SRL, 11, Frasinului Str., Ilfov District, 075100 Bucharest, Romania; \\ ionutmoraru@pro-natura.ro (I.M.); angela.moraru@pro-natura.ro (A.M.) \\ 2 Faculty of Biotechnologies, University of Agronomic Sciences and Veterinary Medicine of Bucharest, \\ 011464 Bucharest, Romania; teodoracristinaa@yahoo.com \\ 3 National Institute of Research and Development for Biological Sciences, 296, Splaiul Independenței, \\ 060031 București, Romania; alex.gaspar@yahoo.com (A.G.-P.); vivi_ana12@yahoo.com (V.C.); \\ lauramihaelastefan@yahoo.com (L.S.); andreea.iosageanu@gmail.com (A.I.); \\ danielailiee24@gmail.com (D.I.); catalinapetrareanu@yahoo.com (C.S.); ana.seciu@yahoo.com (A.-M.S.-G.) \\ * Correspondence: oancea.anca@gmail.com \\ + Presented at the 16th International Symposium "Priorities of Chemistry for a Sustainable Development" \\ PRIOCHEM, Bucharest, Romania, 28-30 October 2020.
}

Published: 11 November 2020

Keywords: fermented colostrum; peptides; nutraceuticals; cosmeceuticals

Introduction: Nutraceuticals are food or parts of a food that provide medicinal or health benefits, including the prevention and treatment of disease. Cosmeceuticals are the cosmetic products that incorporate biologically active ingredients having therapeutic benefits on the surface applied. Within SC LABORATOARELE MEDICA, fermented colostrum is obtained with enhanced kefir grains using an original method [1]. The fermented product contains low molecular weight (LMW) peptides that have been isolated and characterized [2,3]. The aim of this paper was to evaluate the potential of these peptides in the prevention of certain diseases so as to apply the active principles in the formulas of some nutraceuticals and cosmeceuticals obtained by this company.

Materials and methods:

- Bovine colostrum was fermented with enhanced kefir grains;

- Quantitative determination of LMW peptides from fermented colostrum was performed using o-pthaldialdehyde (OPA) reagent;

- The qualitative determination of the peptides was performed with Tricine-SDS-PAGE;

- Antioxidant activity of peptides was determined using the ABTS method;

- Angiotensin converting enzyme (ACE) inhibitory potential was evaluated by the method described by Papadimitriou et al. [4];

- The recovery effect was evaluated in vitro through a scratch assay experiment;

- The evaluation of the anti-inflammatory effect was performed using a specific ELISA kit for cytokines TNF- $\alpha$, IL- 6 and IL- $\beta$.

Results: Bovine colostrum fermented with a consortium of improved kefir, conditioned in powder form by atomization, by its content of bioactive peptides showed the following characteristics: antioxidant effect, ACE inhibitory activity (so blood pressure regulation), 
biocompatibility, healing and anti-inflammatory effect. Due to these characteristics, it is included in the following nutraceutical formulas: Col-Kefir, Super-Nutrient, Focus 3xbiotics, Pan Verucidin. These nutraceuticals are considered tri-biotic products because their pre-, pro- and post-biotic effects have been determined. The COL-KEFIR MILK THERAPY product line, which is part of the cosmeceuticals category, consists of biocompatible products, with healing, anti-inflammatory and antibacterial effects.

Conclusions: Fermented bovine colostrum, by its content of bioactive peptides, is a safe and useful nutraceutical product for use in a wide range of applications. In addition, peptides from this source are useful for the development of cosmetic formulations aimed at treating damaged and dysfunctional skin.

Acknowledgments: This work was supported by a Grant of the Romanian Ministry of Research and Innovation, CCCDI-UEFISCDI, project no. PN-III-P3-3.5-EUK-2017-02-0026/2018.

\section{References}

1. Cotârleț, M.; Vasile, A.M.; Gaspar-Pintiliescu, A.; Oancea, A.; Bahrim, G.E. Tribiotication strategy for the functionalization of bovine colostrum through the biochemical activities of artisanal and selected starter cultures. CyTA J. Food 2020, 18, 274-280.

2. Gaspar-Pintiliescu, A.; Oancea, A.; Cotârleț, M.; Vasile, A.M.; Bahrim, G.E.; Shaposhnikov, S.; Crăciunescu, O.; Oprița, E.I. Angiotensin-converting enzyme inhibition, antioxidant activity and cytotoxicity of bioactive peptides from fermented bovine colostrum. Int. J. Dairy Technol. 2020, 73, 108-116.

3. Cotârleț, M.; Vasile, A.M.; Cantaragiu, A.M.; Gaspar-Pintiliescu, A.; Crăciunescu, O.; Oancea, A.; Moraru, A.; Moraru, I.; Bahrim, G.E. Colostrum-derived bioactive peptides obtained by fermentation with Kefir grains enriched with selected yeasts. Ann. Univ. Dunărea Jos Galați Fascicle VI Food Technol. 2019, 43, 54-68.

4. Papadimitriou, C.G.; Vafopoulou-Mastrojiannaki, A.; Silva, S.V.; Gomes, A.-M.; Malcata, F.X.; Alichanidis, E. Identification of peptides in traditional and probiotic sheep milk yoghurt with angiotensin I-converting enzyme (ACE)-inhibitory activity. Food Chem. 2007, 105, 647-656.

Publisher's Note: MDPI stays neutral with regard to jurisdictional claims in published maps and institutional affiliations.

() 2020 by the authors. Licensee MDPI, Basel, Switzerland. This article is an open access article distributed under the terms and conditions of the Creative Commons Attribution (CC BY) license (http://creativecommons.org/licenses/by/4.0/). 